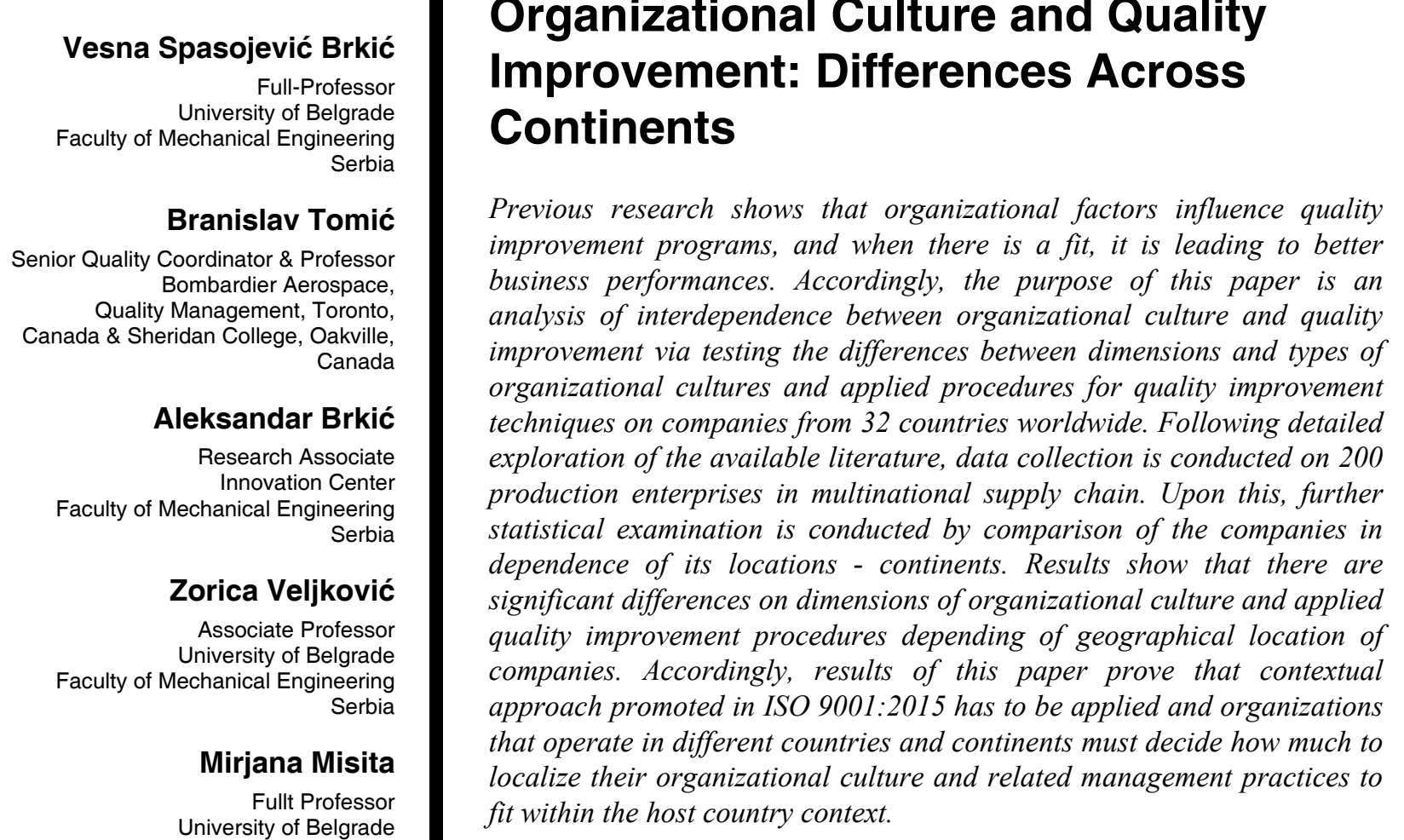

Faculty of Mec

\section{Organizational Culture and Quality Improvement: Differences Across Continents}

Previous research shows that organizational factors influence quality improvement programs, and when there is a fit, it is leading to better business performances. Accordingly, the purpose of this paper is an analysis of interdependence between organizational culture and quality improvement via testing the differences between dimensions and types of organizational cultures and applied procedures for quality improvement techniques on companies from 32 countries worldwide. Following detailed exploration of the available literature, data collection is conducted on 200 production enterprises in multinational supply chain. Upon this, further statistical examination is conducted by comparison of the companies in dependence of its locations - continents. Results show that there are significant differences on dimensions of organizational culture and applied quality improvement procedures depending of geographical location of companies. Accordingly, results of this paper prove that contextual approach promoted in ISO 9001:2015 has to be applied and organizations that operate in different countries and continents must decide how much to fit within the host country context.

Keywords: Organizational culture, Quality improvement, Differences, Multinational company, Countries an continents.

\section{INTRODUCTION}

In scientific and professional literature there exist few studies which consider subject of interaction of the organizational culture and quality improvement. In the recent years this topic gains more interest following the search for reasons of pitfalls of the large number of quality improvement initiatives. Using simple analysis and following tracks where initiatives come across insurmountable obstacles, leads to definition of organizational cultures and their influence on conducting and reasoning of workers on the places where quality improvement have essential role. Although this field is still is insufficiently researched, influence of organizational culture on selection of the adequate programs for quality improvement is notably significant and there exists important interdependence.

Resulting behavior of the employees is guided by organizational culture and it is a main prerequisite for continuous and systematic quality improvement that include all employees in the company [3,4,7,16,27]. Hence, organizational culture has strong influence on the essential dimension representing basis of every initiative for quality improvement, and therefore must be supported and guided from top executives and CEO's in the company $[6,9,10,23,24]$ with a goal of advancement of the companies' business performances [25].

Received: October 2019, Accepted: December 2019

Correspondence to: Dr Vesna Spasojevic-Brkic

Faculty of Mechanical Engineering,

Kraljice Marije 16, 11120 Belgrade 35, Serbia

E-mail: vspasojevic@mas.bg.ac.rs

doi:10.5937/fme2002372S

(C) Faculty of Mechanical Engineering, Belgrade. All rights reserved
Accordingly, organizational culture should be compatible with quality improvement programs in the way that supports them $[18,22,26]$. This leads to the need for additional detailed exploration of the interdependence between dimensions defining organizational culture and quality improvement, since differences between nationalities and their culture and quality improvement additionally raise questions about contextual dependence on the choice of the adequate programs for quality improvement. Also, nowadays, competition has moved from the scale of single companies to the supply chain level and the supply chain members act as "partners" that have to satisfy customers all over the world.

In that context this paper first presents review of existing research in this field, following by an analysis of dimensions of the organizational culture and quality improvement on the sample of 200 companies from 32 countries which are part of supply chain of the large international company. Analysis of two different concepts was conducted and they are compared depending of geographical location of the companies, i.e. of the continent where company is redistricted.

\section{REVIEW OF THE EXISTING EMPIRICAL RESE- ARCHES IN THE FIELD OF ORGANIZATIONAL CULTURE AND QUALITY IMPROVEMENT}

In Table 1 the most important empirical researches in the field of influence of the organizational culture on quality management are presented.

Based on analyzed literature review and realized empirical research, it can be concluded that organizational culture has significant, but not enough explored impact on quality improvement processes. 
Table 1. Review and analysis previous research on the influence of organizational culture on quality improvement programs (adapted from $[1,2,3,4,5,8,11,12,13,14,15,17,18,19,20,21,28]$ )

\begin{tabular}{|c|c|c|c|c|c|}
\hline \# & Research & Method & Organizational culture & Quality improvement & Conclusions \\
\hline 1 & $\begin{array}{l}\text { Rad } \\
(2006)\end{array}$ & $\begin{array}{l}\text { Survey: } \\
\text { Likert scale from } \\
1 \text { to } 5 \\
\text { Statistical } \\
\text { analysis: } \\
\chi^{2} \text { test, } U^{*} \text { and } \\
\text { Kruskall-Wallis } \\
\text { tests }\end{array}$ & $\begin{array}{l}\text { Strong organizational culture: } \\
\text { 1. avoidance of uncertainties } \\
\text { 2. long-term orientation (goals) } \\
\text { 3. creativity } \\
\text { 4. collectivism } \\
\text { 5. flexibility } \\
\text { 6. collaboration } \\
\text { 7. detail oriented } \\
\text { 8. anticipation } \\
\text { 9. stability } \\
\text { 10. innovation } \\
\text { 11. learning } \\
\text { 12. organic organizational structure } \\
\text { 13. risk taking } \\
\\
\text { weak organizational culture } \\
\text { 1. remote management (control) } \\
\text { 2. discrimination } \\
\text { 3. uncertainty } \\
\text { 4. individualism } \\
\text { 5. bureaucratic or mechanical } \\
\text { organizational structure } \\
\text { 6. short term goals }\end{array}$ & $\begin{array}{l}\text { 8 principles of TQM: } \\
\text { 1. leadership and } \\
\text { management } \\
\text { 2. strategic planning } \\
\text { 3. orientation toward } \\
\text { customers } \\
\text { 4. focus on employees } \\
\text { 5. orientation toward } \\
\text { subcontractors } \\
\text { 6. focus on material } \\
\text { recourses } \\
\text { 7. management of processes } \\
\text { 8. results of performances }\end{array}$ & $\begin{array}{l}\text { In order to achieve } \\
\text { significant quality } \\
\text { improvement, dominant } \\
\text { organizational culture } \\
\text { must be compatible } \\
\text { with values and basic } \\
\text { principles of TQM. } \\
\text { Managers responsible } \\
\text { for TQM } \\
\text { implementation can } \\
\text { choose between two } \\
\text { proposed alternatives: } \\
\text { to harmonize TQM } \\
\text { implementation process } \\
\text { with existing } \\
\text { organizational culture } \\
\text { or to try to change } \\
\text { culture without } \\
\text { adjustment of } \\
\text { implementation process. }\end{array}$ \\
\hline 2 & $\begin{array}{l}\text { Kujala and } \\
\text { Lillrank } \\
\text { (2004) }\end{array}$ & $\begin{array}{l}\text { Statistical } \\
\text { analysis: } \\
\text { qualitative data } \\
\text { analysis }\end{array}$ & $\begin{array}{l}\text { Schein model of organizational } \\
\text { culture }\end{array}$ & $\begin{array}{l}\text { Organizational mission and } \\
\text { communicative goals: } \\
\text { 1. focus on results } \\
\text { 2. orientation toward } \\
\text { customers } \\
\text { Approach toward } \\
\text { management and } \\
\text { organizational decision } \\
\text { making process: } \\
\text { 1. continual improvements } \\
\text { 2. facts based management } \\
\text { Role of management and } \\
\text { employee involvement: } \\
\text { 1. leadership } \\
\text { 2. employee evaluation } \\
\text { Planning, coordination and } \\
\text { scheduling: } \\
\text { 1. long term perspectives } \\
\text { 2. projection of quality } \\
\text { 3. system approach } \\
\text { 4. development of } \\
\text { partnerships } \\
\text { 5. fast reactions }\end{array}$ & $\begin{array}{l}\text { TQM can be analyzed } \\
\text { as a cultural } \\
\text { phenomenon with } \\
\text { coherent group basic } \\
\text { assumptions forming } \\
\text { ideal quality culture. } \\
\text { Quality culture can be } \\
\text { regarded as the } \\
\text { theoretical basis for } \\
\text { TQM. }\end{array}$ \\
\hline 3 & $\begin{array}{l}\text { Boggs } \\
(2004)\end{array}$ & $\begin{array}{l}\text { Survey: } \\
\text { Likert scale from } \\
1 \text { to } 7 \\
\text { Statistical } \\
\text { analysis: } \\
\text { descriptive } \\
\text { statistics and } \\
\text { quantitative } \\
\text { analysis }\end{array}$ & $\begin{array}{l}\text { Quinn and Rohrabaugh typology of } \\
\text { organizational culture }\end{array}$ & $\begin{array}{l}7 \text { theoretical concepts that } \\
\text { represent strongholds of } \\
\text { TQM: } \\
\text { 1. visionary leadership } \\
\text { 2. internal and external } \\
\text { cooperation } \\
\text { 3. learning } \\
\text { 4. process management } \\
\text { 5. continuous improvement } \\
\text { 6. satisfaction of employees } \\
\text { 7. customer satisfaction }\end{array}$ & $\begin{array}{l}\text { First, emphasis on team } \\
\text { work, continual } \\
\text { improvement and long- } \\
\text { term vision is effective } \\
\text { in application of TQM } \\
\text { values. } \\
\text { Secondly clan culture is } \\
\text { stronger than hierarchy, } \\
\text { adhocracy and market } \\
\text { cultures. Also program } \\
\text { of TQM is more based } \\
\text { on hierarchy then on } \\
\text { adhocracy culture. }\end{array}$ \\
\hline 4 & $\begin{array}{l}\text { Luria and } \\
\text { Gil (2008) }\end{array}$ & $\begin{array}{l}\text { Survey: } \\
\text { Likert scale from } \\
1 \text { to } 5\end{array}$ & $\begin{array}{l}\text { Schein model of organizational } \\
\text { culture }\end{array}$ & $\begin{array}{l}\text { Aspects of leadership in } \\
\text { quality: } \\
\text { 1. quality climate } \\
\text { 2. transformative leadership }\end{array}$ & $\begin{array}{l}\text { First, behavioral models } \\
\text { of employees are not in } \\
\text { coordination with } \\
\text { formal principles }\end{array}$ \\
\hline
\end{tabular}




\begin{tabular}{|c|c|c|c|c|c|}
\hline & & $\begin{array}{l}\text { Statistical } \\
\text { analysis: } \\
\text { quantitative } \\
\text { analysis, factor } \\
\text { analysis and } \\
\text { ANOVA between } \\
\text { the groups }\end{array}$ & & $\begin{array}{l}\text { 3. unwanted behavior } \\
\text { regarding the quality }\end{array}$ & $\begin{array}{l}\text { defining desired } \\
\text { behavior for achieving } \\
\text { quality desired by upper } \\
\text { management. } \\
\text { Second, behavior of } \\
\text { employees is much } \\
\text { better in organizations } \\
\text { or companies with } \\
\text { highly developed } \\
\text { quality surroundings } \\
\text { and flexible and } \\
\text { adaptive type of } \\
\text { leadership used for the } \\
\text { transformations and } \\
\text { adoptions to current } \\
\text { environment. }\end{array}$ \\
\hline 5 & $\begin{array}{l}\text { Pool } \\
(2000)\end{array}$ & $\begin{array}{l}\text { Statistical } \\
\text { analysis: } \\
\text { structural } \\
\text { equation analysis }\end{array}$ & $\begin{array}{l}5 \text { construct of organizational } \\
\text { structure - not specified }\end{array}$ & $\begin{array}{l}6 \text { constructs of TQM - not } \\
\text { specified }\end{array}$ & $\begin{array}{l}\text { Result show positive } \\
\text { and significant } \\
\text { correlation between } \\
\text { principles of TQM and } \\
\text { organizational culture }\end{array}$ \\
\hline 6 & $\begin{array}{l}\text { Cameron } \\
\text { and Sine } \\
(1999)\end{array}$ & $\begin{array}{l}\text { Survey: } \\
\text { Likert scale from } \\
1 \text { to } 6 \\
\text { Statistical } \\
\text { analysis: } \\
\text { Cronbach } \alpha \\
\text { coefficient, } \chi^{2} \\
\text { test, factor } \\
\text { analysis and } \\
\text { correlation }\end{array}$ & $\begin{array}{l}\text { Schein model of organizational } \\
\text { culture }\end{array}$ & $\begin{array}{l}\text { 1. lack of emphasis on } \\
\text { quality } \\
\text { 2. identification of mistakes } \\
\text { 3. prevention of mistakes } \\
\text { 4. creativity in quality }\end{array}$ & $\begin{array}{l}\text { TQM is primarily } \\
\text { cultural phenomenon } \\
\text { rather than simple } \\
\text { application of the set of } \\
\text { quality tools and } \\
\text { techniques. Authors } \\
\text { claim that successful } \\
\text { implementation of the } \\
\text { TQM primarily is } \\
\text { influenced by } \\
\text { compatibility of } \\
\text { organizational culture } \\
\text { and existing quality } \\
\text { climate in the company. } \\
\text { Results of the research } \\
\text { shows significant } \\
\text { correlation between } \\
\text { electivity of the quality } \\
\text { improvement } \\
\text { procedures and } \\
\text { advanced level of } \\
\text { culture of the quality. } \\
\text { Other factors } \\
\text { influencing on quality } \\
\text { culture are considered } \\
\text { such as: national } \\
\text { cultures, types of } \\
\text { organization and way } \\
\text { how they operate etc. }\end{array}$ \\
\hline 7 & $\begin{array}{l}\text { Zu et al. } \\
(2010)\end{array}$ & $\begin{array}{l}\text { Survey: } \\
\text { Likert scale } \\
\text { Statistical } \\
\text { analysis: } \\
\text { structural } \\
\text { equation analysis }\end{array}$ & $\begin{array}{l}\text { Quinn and Rohrabaugh typology of } \\
\text { organizational culture }\end{array}$ & $\begin{array}{l}\text { 1. support of top level } \\
\text { management } \\
\text { 2. customer relationships } \\
\text { 3. relationship with } \\
\text { subcontractors } \\
\text { 4. employee management } \\
\text { 5. information's relevant to } \\
\text { quality } \\
\text { 6. product design } \\
\text { 7. process management } \\
\text { 8. structure of roles in six } \\
\text { sigma methodology } \\
\text { 9. structural procedure of six } \\
\text { sigma } \\
\text { 10. focus of measurement } \\
\text { phase in six sigma } \\
\text { methodology }\end{array}$ & $\begin{array}{l}\text { Main conclusion of this } \\
\text { research is that is } \\
\text { necessary to determine } \\
\text { and recognize existing } \\
\text { organizational culture } \\
\text { before initializing any } \\
\text { quality improvement } \\
\text { initiative. }\end{array}$ \\
\hline 8 & $\begin{array}{l}\text { Jung et al. } \\
(2008)\end{array}$ & $\begin{array}{l}\text { Survey: } \\
\text { Likert scale from } \\
1 \text { to } 5 \\
\end{array}$ & $\begin{array}{l}\text { Expanded Hofstade typology of } \\
\text { organizational structure (with long } \\
\text { term orientation) }\end{array}$ & $\begin{array}{l}\text { 1. leadership } \\
\text { 2. strategic planning } \\
\text { 3. focus on costumers and }\end{array}$ & $\begin{array}{l}\text { Organizational culture } \\
\text { based on national } \\
\text { culture have }\end{array}$ \\
\hline
\end{tabular}




\begin{tabular}{|c|c|c|c|c|c|}
\hline & & $\begin{array}{l}\text { Statistical } \\
\text { analysis: } \\
\text { descriptive } \\
\text { statistics and } \\
\text { factor analysis }\end{array}$ & & \begin{tabular}{|l|} 
market \\
4. measurements, analysis \\
and knowledge management \\
5. focus on human resources \\
6. process management \\
7. business results
\end{tabular} & $\begin{array}{l}\text { exceptionally important } \\
\text { role in process of } \\
\text { quality management, } \\
\text { with emphasis on power } \\
\text { distance as a sub } \\
\text { typology with the } \\
\text { highest effect on an } \\
\text { implementation of } \\
\text { quality improvement } \\
\text { initiatives. }\end{array}$ \\
\hline 9 & $\begin{array}{l}\text { Prajogo } \\
\text { and } \\
\text { McDermo } \\
\text { nt (2005) }\end{array}$ & \begin{tabular}{|l} 
Statistical \\
analysis: \\
structural \\
equation analysis \\
and confirmatory \\
factor analysis
\end{tabular} & $\begin{array}{l}\text { Quinn's and Rohrabaugh's typology } \\
\text { of organizational culture }\end{array}$ & $\begin{array}{l}\text { 1. leadership } \\
\text { 2. strategic planning } \\
\text { 3. focus on costumers } \\
\text { 4. information's and analysis } \\
\text { 5. management of employees } \\
\text { 6. process management } \\
\end{array}$ & $\begin{array}{l}\text { This research point to } \\
\text { most adequate questions } \\
\text { or singularly optimal } \\
\text { organizational culture, } \\
\text { or combination of the } \\
\text { organizational cultures } \\
\text { that affect quality } \\
\text { management process. } \\
\end{array}$ \\
\hline 10 & $\begin{array}{l}\text { Man } \\
(2005)\end{array}$ & $\begin{array}{l}\text { Statistical } \\
\text { analysis: } \\
\text { Kruskall-Wallis } \\
\text { and Spearman } \\
\text { testing }\end{array}$ & $\begin{array}{l}\text { Quinn's and Rohrabaugh's typology } \\
\text { of organizational culture }\end{array}$ & \begin{tabular}{|l|} 
1. top management \\
commitment and leadership \\
2. process structure and \\
organization for continual \\
improvements \\
3. achievement of necessary \\
business performances \\
4. relations with \\
subcontractors \\
5. employee trainings \\
6. understanding, \\
commitment and satisfaction \\
of employees \\
7. communication \\
8. team work \\
9. objective measurements \\
and feedback
\end{tabular} & $\begin{array}{l}\text { Best organizational } \\
\text { culture sub-typologies } \\
\text { for successful TQM } \\
\text { implementation are clan } \\
\text { and hierarchy cultures. }\end{array}$ \\
\hline 11 & $\begin{array}{l}\text { Butler } \\
(2009)\end{array}$ & $\begin{array}{l}\text { Statistical } \\
\text { analysis: } \\
\text { Student t-test }\end{array}$ & $\begin{array}{l}\text { 1. culture of equality } \\
\text { 2. commitment culture } \\
\text { 3. culture for development } \\
\text { 4. culture for empowerment }\end{array}$ & $\begin{array}{l}\text { 1. examination of } \\
\text { organizational planning and } \\
\text { goals } \\
\text { 2. preparation of } \\
\text { organization planning for } \\
\text { training } \\
\text { 3. training preparation } \\
\text { 4. training implementation } \\
\text { 5. training results }\end{array}$ & $\begin{array}{l}\text { Employee factor is key } \\
\text { element in establishing } \\
\text { and developing of } \\
\text { system of quality } \\
\text { management in any } \\
\text { enterprise. }\end{array}$ \\
\hline 12 & $\begin{array}{l}\text { Ionescu } \\
\text { and } \\
\text { Bratosin } \\
(2009)\end{array}$ & $\begin{array}{l}\text { Statistical } \\
\text { analysis: } \\
\text { Student t-test }\end{array}$ & $\begin{array}{l}\text { Handy's typology of organizational } \\
\text { culture interacted with } 14 \\
\text { dimensions: } \\
\text { 1. type of lower managers } \\
\text { 2. type of "good" subordinates } \\
\text { 3. modus decision of priorities } \\
\text { 4. type of employees that company } \\
\text { promote } \\
\text { 5. the way on which company treats } \\
\text { their employees } \\
\text { 6. models of the control and the } \\
\text { influences in company } \\
\text { 7. applied models for tack } \\
\text { distribution } \\
\text { 8. types of employees motivation for } \\
\text { task fulfillment } \\
\text { 9. team work } \\
\text { 10. competition between teams } \\
\text { 11 the ways company confronts and } \\
\text { manages conflicts } \\
\text { 12. the way of decision making } \\
\text { 13. models for internal } \\
\text { communications in company } \\
\text { 14. the ways on which company } \\
\text { reacts on external influences }\end{array}$ & \begin{tabular}{|l|} 
1. successfully completed \\
tasks \\
2. stimulation of internal \\
competiveness \\
3. creation of trust climate \\
4. optimization of \\
communications \\
5. barrier elimination \\
6. collaboration \\
7. transparency \\
8. flexibility of rules that \\
enables improvements \\
9. employee training \\
10. employee inclusion \\
11. keeping satisfaction of \\
customers \\
12. organizational dedication \\
13. team work \\
14. role flexibility \\
15. management of customer \\
satisfaction through \\
continuous improvements
\end{tabular} & $\begin{array}{l}\text { Research shows that } \\
\text { dominant sub-typology } \\
\text { is task culture for } \\
\text { companies gravitating } \\
\text { to quality improvement. } \\
\text { Following important } \\
\text { sub-typologies are } \\
\text { culture of power and } \\
\text { culture of roles, while at } \\
\text { least impact has culture } \\
\text { of support. }\end{array}$ \\
\hline 13 & Corbett & & This research uses methodology & Quality indicators are based & Results of this research \\
\hline
\end{tabular}




\begin{tabular}{|c|c|c|c|c|c|}
\hline & \begin{tabular}{|l} 
and \\
Rastrick \\
$(2000)$
\end{tabular} & $\begin{array}{l}\text { Likert scale from } \\
1 \text { to } 5 \\
\text { Statistical } \\
\text { analysis: } \\
\text { Spearman } \\
\text { correlation rank } \\
\text { test }\end{array}$ & $\begin{array}{l}\text { based on dividing organizational } \\
\text { culture by styles: } \\
\text { 1. Passive or defensive style } \\
\text { 2. Aggressive or offensive stile } \\
3 \text { Constructive style }\end{array}$ & $\begin{array}{l}\text { on: } \\
\text { 1. percentage of defect } \\
\text { 2. quality costs } \\
\text { 3. percentage of inspection } \\
\text { inclusion } \\
\text { 4. percentage of delivery } \\
\text { 5. guarantee complaints } \\
\text { 6. percentage defective } \\
\text { materials and parts from } \\
\text { subcontractors }\end{array}$ & $\begin{array}{l}\text { indicate that the } \\
\text { constructive style is the } \\
\text { best management style } \\
\text { for achieving good } \\
\text { quality performances. } \\
\text { Lack of leadership from } \\
\text { top managerial } \\
\text { structures, adequate } \\
\text { training, selection of the } \\
\text { employees, work habits } \\
\text { and structure of } \\
\text { supervising work tasks, } \\
\text { initiatives for changes } \\
\text { in organizational culture } \\
\text { have small chances of } \\
\text { success. }\end{array}$ \\
\hline 14 & $\begin{array}{l}\text { Mathew } \\
(2007)\end{array}$ & $\begin{array}{l}\text { Statistical } \\
\text { analysis: } \\
\text { Student t-test }\end{array}$ & $\begin{array}{l}\text { Organizational culture is identified } \\
\text { as: } \\
\text { 1. empowerment } \\
\text { 2. agreement } \\
\text { 3. integrity and basic values } \\
\text { 4. knowledge distribution and } \\
\text { organizational learning } \\
\text { 5. care for employees and trust in } \\
\text { them } \\
\text { 6. company mission } \\
\text { 7. customer oriented company } \\
\text { 8. high performances with goal in } \\
\text { success }\end{array}$ & $\begin{array}{l}\text { quality items included in this } \\
\text { research are: } \\
\text { 1. focus on quality } \\
\text { 2. employee concern for } \\
\text { quality } \\
\text { 3. prompt reactions on } \\
\text { customers complains } \\
\text { 4. seriousness and respect of } \\
\text { delivery times } \\
\text { 5. quality system that } \\
\text { enables achievement of } \\
\text { customer requested level of } \\
\text { quality }\end{array}$ & $\begin{array}{l}\text { There exists strong } \\
\text { correlation between } \\
\text { organizational culture } \\
\text { and achieved level of } \\
\text { quality. }\end{array}$ \\
\hline 15 & $\begin{array}{l}\text { Noar et al. } \\
(2008)\end{array}$ & $\begin{array}{l}\text { Survey: } \\
\text { Likert scale from } \\
1 \text { to } 7 \\
\text { Statistical } \\
\text { analysis: } \\
\text { structural } \\
\text { equation analysis }\end{array}$ & $\begin{array}{l}\text { Quinn and Rohrabaugh typology of } \\
\text { organizational culture }\end{array}$ & $\begin{array}{l}\text { Infrastructural practice for } \\
\text { quality management contains } \\
\text { following elements: } \\
\text { 1. top management support } \\
\text { 2. management of employees } \\
\text { 3. supplier inclusion } \\
\text { 4. customer inclusion } \\
\text { Elements of essential } \\
\text { practices for quality } \\
\text { management are: } \\
\text { 1. information's about } \\
\text { quality } \\
\text { 2. process management } \\
\text { 3. product design }\end{array}$ & $\begin{array}{l}\text { Organizational culture } \\
\text { has stronger influence } \\
\text { on infrastructures of } \\
\text { practice for quality } \\
\text { improvement than on } \\
\text { core quality } \\
\text { improvement, } \\
\text { regardless of other } \\
\text { factor influences. } \\
\text { Furthermore } \\
\text { conclusions can be } \\
\text { drawn that } \\
\text { infrastructural practices } \\
\text { of quality management } \\
\text { have significant effect } \\
\text { on the production } \\
\text { performances of the } \\
\text { company. }\end{array}$ \\
\hline 16 & $\begin{array}{l}\text { Detert et } \\
\text { al. }(2000)\end{array}$ & $\begin{array}{l}\text { Statistical } \\
\text { analysis: } \\
\text { Descriptive } \\
\text { statistics }\end{array}$ & $\begin{array}{l}\text { Eight dimensions of organizational } \\
\text { culture are in use: } \\
\text { 1. foundations for verity and } \\
\text { rationalization in company } \\
\text { 2. time and time horizons natures } \\
\text { 3. motivation } \\
\text { 4. stability v.s. } \\
\text { changes/innovations/personal } \\
\text { development } \\
\text { 5. orientation toward work, tasks and } \\
\text { mutual cooperation } \\
\text { 6. isolation v.s. } \\
\text { collaboration/cooperation } \\
\text { 7. control, coordination and } \\
\text { responsibility } \\
\text { 8. internal and external orientations } \\
\text { and focus }\end{array}$ & $\begin{array}{l}8 \text { dimensions of the TQM } \\
\text { are: } \\
\text { 1. decision making based on } \\
\text { facts and scientific methods } \\
\text { 2. improvement of the } \\
\text { requirements for long term } \\
\text { orientation and strategic } \\
\text { approach } \\
\text { 3. quality problems caused by } \\
\text { inadequate systems rather } \\
\text { than employee structure } \\
\text { 4. quality improvement is } \\
\text { ongoing process } \\
5 . \text { main purpose of existing of } \\
\text { organization is achievement } \\
\text { of results which are essential } \\
\text { for interested groups } \\
6 . \text { cooperation and } \\
\text { collaboration are necessary } \\
\text { for successful functioning of } \\
\text { the organization } \\
\text { 7. vision and goals must be } \\
\text { clearly defined and represent }\end{array}$ & $\begin{array}{l}\text { Dimensions of culture } \\
\text { have influence on } \\
\text { creation of ideal culture } \\
\text { for successful TQM } \\
\text { improvement initiatives. }\end{array}$ \\
\hline
\end{tabular}




\begin{tabular}{|c|c|c|c|c|c|}
\hline & & & & $\begin{array}{l}\text { necessity for company } \\
\text { success } \\
8 . \text { organization must react on } \\
\text { customer requirements } \\
\text { resulting in adequate } \\
\text { financial gains. }\end{array}$ & \\
\hline 17 & $\begin{array}{l}\text { Lagrosen } \\
(2003)\end{array}$ & $\begin{array}{l}\text { Survey: } \\
\text { Likert scale from } \\
1 \text { to } 5 \\
\text { Statistical } \\
\text { analysis: } \\
\text { Pearson } \\
\text { correlation test }\end{array}$ & $\begin{array}{l}\text { Hofstade's typology of } \\
\text { organizational structure }\end{array}$ & $\begin{array}{l}\text { Values of TQM are: } \\
\text { 1. orientation toward } \\
\text { customers } \\
\text { 2. dedication toward } \\
\text { leadership } \\
\text { 3. overall full participation } \\
\text { 4. focus on business process } \\
\text { 5. continual improvements } \\
\text { 6. focus on measurements }\end{array}$ & $\begin{array}{l}\text { Conclusions of this } \\
\text { research indicate that } \\
\text { significant correlations } \\
\text { exist, primary between } \\
\text { avoiding uncertainties } \\
\text { and individuality i.e. } \\
\text { collectivism from one } \\
\text { side and quality } \\
\text { management from other. } \\
\text { Cultures with high } \\
\text { avoidance of } \\
\text { uncertainties values are } \\
\text { focused on business } \\
\text { process and continual } \\
\text { improvement can cause } \\
\text { significantly harder } \\
\text { implementation. In the } \\
\text { countries with lower } \\
\text { level of avoidance of } \\
\text { uncertainties exists great } \\
\text { tendency for the focus } \\
\text { on several important } \\
\text { buyers. Also, countries } \\
\text { with individualistic } \\
\text { organizational culture } \\
\text { and high avoidance of } \\
\text { uncertainties tend to } \\
\text { treat all buyers equally. }\end{array}$ \\
\hline 18 & $\begin{array}{l}\text { Kull and } \\
\text { Wacker } \\
(2010)\end{array}$ & \begin{tabular}{|l|} 
Statistical \\
analysis: \\
linear hierarchical \\
modeling
\end{tabular} & $\begin{array}{l}\text { Modified Hofstade's typology of } \\
\text { organizational structure with } \\
\text { following dimensions: } \\
\text { 1. orientation toward future } \\
\text { 2. institutional collectivism } \\
\text { 3. employee oriented company } \\
\text { 4. avoidance of uncertainties } \\
\text { 5. self-assurance } \\
\text { 6. hierarchy range from power } \\
\text { 7. Group collectivism } \\
\text { 8. Performance oriented companies }\end{array}$ & $\begin{array}{l}\text { Values of quality } \\
\text { management are: } \\
\text { 1. decision making based on } \\
\text { facts and science } \\
\text { 2. improvement is long term } \\
\text { and strategic concept } \\
\text { 3. problems are systematic } \\
\text { 4. improvement is the endless } \\
\text { process which is achieved } \\
\text { with existing resources } \\
\text { 5. for interested groups } \\
\text { results are achieving through } \\
\text { internal changes, prevention } \\
\text { and customer orientation } \\
\text { 6. cooperation and } \\
\text { collaboration are necessary } \\
\text { 7. transparent vision is the } \\
\text { requisite for success with } \\
\text { employees included in } \\
\text { decision making } \\
\text { 8. monitoring customer } \\
\text { requirements will be followed } \\
\text { with financial results }\end{array}$ & $\begin{array}{l}\text { This research have } \\
\text { following conclusions: } \\
\text { 1. High self-confidence } \\
\text { is correlated with low } \\
\text { effectiveness of quality } \\
\text { management. } \\
\text { 2. High level of the } \\
\text { uncertainties avoidance } \\
\text { is correlated with high } \\
\text { effectiveness of quality } \\
\text { management. }\end{array}$ \\
\hline 19 & $\begin{array}{l}\text { Kaluarach } \\
\text { chi }(2010)\end{array}$ & $\begin{array}{l}\text { Statistical } \\
\text { analysis: } \\
\text { qualitative data } \\
\text { analysis }\end{array}$ & $\begin{array}{l}\text { Hofstade's typology of } \\
\text { organizational structure }\end{array}$ & $\begin{array}{l}7 \text { dimensions of TQM in use } \\
\text { are: } \\
\text { 1. commitment of top } \\
\text { management } \\
\text { 2. commitment of the staff } \\
\text { 3. interested group focuses } \\
\text { 4. integration of the } \\
\text { continual improvements } \\
\text { 5. quality culture } \\
\text { 6. measurement and } \\
\text { feedback and quality } \\
\text { improvement } \\
\text { 7. learning organization }\end{array}$ & $\begin{array}{l}\text { Culture of support has } \\
\text { positive effects on TQM } \\
\text { practice. }\end{array}$ \\
\hline
\end{tabular}




\section{RESEARCH OF THE ORGANIZATIONAL CUL- TURE AND QUALITY IMPROVEMENT IN COMPA- NIES THAT BELONG TO A MULTINATIONAL COMPANY SUPPLY CHAIN}

Empirical research presented in this paper includes all production enterprises and the most important company's suppliers and partners, dispersed on six continents (North America, South America, Europe, Asia, Australia and Africa).

Using survey method, an empirical research is conducted on the sample of 200 enterprises, where more than 10000 data about explored variables.

In order to collect needed data for this study, discrete, five-point Likert scale, with end points of "strongly disagree $(=1)$ " and "strongly agree $(=5)$ ", with middle of the scale representing neutral answer to measure that construct, was used. The respondents needed to mark value of their levels of agreement or disagreement with statement regarding the application of organizational culture dimensions, quality improvement tool or methodology, as well as business performance indicators. According to general recommendations [16], 25\% of question in this survey were recorded and placed in reversed order, for avoiding errors of respondents. To improve survey, five experts and specialists, including university professors and industry professionals were consulted at preliminary phase. Several items in the initial questionnaire were revised as a result of their comments and inputs. The survey was emailed to 500 companies that are parts or subcontractors of the examined large multinational company supply chain.

Responses were received from 200 companies and from 32 different countries widespread on 6 continents.

Descriptive statistic of the researched variables is shown in Table 2.

Correlation analysis of examined variables leads to the following conclusions:

1. Risk management is positively correlated with organizational goals i.e. tasks, formalization level, reward system, conflict management, knowledge and competitiveness. Also, risk management is negatively correlated with the control system. Looking at quality improvement factors, risk management is correlated with all of them except quality techniques and preventive measures. It is also correlated with quality performance and customer satisfaction.

2. Organizational structure is not correlated with conflict management, regarding organizational culture dimension. Also there is no correlation with any of the quality factors as well as with business performances.

3. The speed of organizational reactions is not correlated with any dimension of organizational culture, with any of quality factors as well as with any of business performances. It is interesting to observe that existing correlations are mostly negative.

4. Communication in organization is correlated with organizational goals/objectives, level of formalization, rewarding system and with progress and development. Regarding factors of quality improvement, risk management is correlated with all factors (variables) except quality techniques and preventive measures. Communi- cation in organization is also correlated with marketing and financial performances, performances of employees, quality characteristics and customer satisfaction.

5. Organizational goals/objectives are correlated with level of formalization, reward system, knowledge and competitiveness and with progress and development. Organizational goals/objectives are also in negative correlation with control system. Regarding quality improvement dimension, organizational goals/objectives are in correlation with all factors from quality improvement pool and also with all business performances.

6. The level of formalization is correlated to the reward system, conflict management, with knowledge and competitiveness, as well as with progress and development. Negative correlation exists in case of control system. As for quality improvement dimensions level of formalization is in correlation with all factors of quality improvement as well as with all business performances.

7. Reward system is in correlation with conflict management, knowledge and competitiveness, as well as with progress and development. Negative correlations exist with control system. Reward system is also correlated with all factors for quality improvement and with business performances.

8. Control system, apart from the mentioned negative correlations with risk management, organizational goals/objectives and reward system is not correlated with any other dimension of organizational culture. Negative correlations exist between control system with basic and advanced quality tools, PDCA, TQM and LEAN methodologies, as well as with corrective actions for quality management variables. Regarding the business performance, there are no correlations between them and control system.

9. Conflict management apart mentioned correlation is not correlated with the rest of organizational dimension variables. Regarding quality improvement dimension, conflict management is correlated with almost all factors except basic quality tools, PDCA and preventive actions. It is also correlated with market/financial performances and employee, quality and customer satisfaction performances.

10. Knowledge and competitiveness apart above mentioned correlations is also correlated with progress and development in from the organizational culture variables. It is also correlated with all factors from quality improvement dimension, and all business performances factors except investing and development variable.

11. Progress and development dimensions are correlated only with mentioned variables for organizational dimensions. Regarding quality improvement dimension factors progress and development is correlated with all of them. Also it is in correlation with all business performances except investment/development variable.

12. Primary focus of organization is not correlated with any dimension of organizational culture, neither with any factor of quality improvement dimension or business performances.

13. All factors regarding quality improvement dimensions are mutually correlated. 
Table 2. Descriptive statistics of the researched variables

\begin{tabular}{|c|c|c|c|c|c|c|c|}
\hline Variable & Z & $\begin{array}{l}\stackrel{8}{\infty} \\
\ddot{E} \\
\tilde{E}\end{array}$ & $\stackrel{\Xi}{\Xi}$ & $\sum_{\Sigma}^{\circlearrowright}$ & $\sum_{\Sigma}^{\tilde{\Xi}}$ & 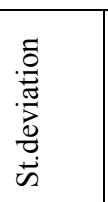 & 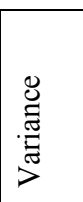 \\
\hline \multicolumn{8}{|c|}{ Organizational Culture dimensions } \\
\hline $\begin{array}{l}\text { Risk } \\
\text { Management }\end{array}$ & 200 & 3.20 & 1.40 & 4.60 & 3.394 & 0.579 & 0.355 \\
\hline $\begin{array}{l}\text { Organizational } \\
\text { Structure }\end{array}$ & 200 & 2.40 & 2.40 & 4.80 & 3.413 & 0.423 & 0.233 \\
\hline $\begin{array}{l}\text { The Speed of } \\
\text { Organizational } \\
\text { reaction }\end{array}$ & 200 & 3.00 & 1.40 & 4.40 & 2.920 & 0.699 & 0.489 \\
\hline $\begin{array}{l}\text { Communication } \\
\text { in Organization }\end{array}$ & 200 & 3.20 & 1.40 & 4.60 & 3.450 & 0.589 & 0.347 \\
\hline $\begin{array}{l}\text { Organizational } \\
\text { Goals/Objectives }\end{array}$ & 200 & 3.00 & 1.80 & 4.80 & 3.634 & 0.583 & 0.340 \\
\hline $\begin{array}{l}\text { The Level of } \\
\text { Formalization }\end{array}$ & 200 & 3.20 & 1.80 & 5.00 & 3.603 & 0.7433 & 0.553 \\
\hline Reward System & 200 & 3.00 & 1.80 & 4.80 & 3.627 & 0.517 & 0.267 \\
\hline Control System & 200 & 3.40 & 1.40 & 4.80 & 2.746 & 0.605 & 0.366 \\
\hline $\begin{array}{l}\text { Conflict } \\
\text { Management }\end{array}$ & 200 & 2.40 & 2.00 & 4.40 & 3.255 & 0.489 & 0.239 \\
\hline $\begin{array}{l}\text { Knowledge and } \\
\text { Competitiveness }\end{array}$ & 200 & 2.80 & 1.80 & 4.60 & 3.390 & 0.556 & 0.309 \\
\hline $\begin{array}{l}\text { Progress and } \\
\text { Development }\end{array}$ & 200 & 4.00 & 1.00 & 5.00 & 3.460 & 0.879 & 0.772 \\
\hline $\begin{array}{l}\text { Primary Focus } \\
\text { of the } \\
\text { Organization }\end{array}$ & 200 & 3.40 & 1.20 & 4.60 & 3.025 & 0.630 & 0.398 \\
\hline \multicolumn{8}{|c|}{ Quality improvement Dimensions } \\
\hline $\begin{array}{l}\text { Basic Quality } \\
\text { Tools }\end{array}$ & 200 & 3.14 & 1.86 & 5.00 & 3.984 & 0.650 & 0.423 \\
\hline $\begin{array}{l}\text { Advanced } \\
\text { Quality Tools }\end{array}$ & 200 & 2.28 & 1.57 & 4.43 & 3.308 & 0.567 & 0.322 \\
\hline $\begin{array}{l}\text { Quality } \\
\text { Techniques }\end{array}$ & 200 & 2.31 & 1.78 & 4.08 & 2.918 & 0.742 & 0.223 \\
\hline PDCA & 200 & 3.00 & 2.00 & 5.00 & 4.218 & 0.462 & 0.412 \\
\hline Kaizen & 200 & 4.00 & 1.00 & 5.00 & 3.963 & 0.736 & 0.542 \\
\hline Six Sigma & 200 & 4.00 & 1.00 & 5.00 & 3.563 & 0.884 & 0.781 \\
\hline TQM & 200 & 3.33 & 1.67 & 5.00 & 3.893 & 0.714 & 0.510 \\
\hline $\begin{array}{l}\text { Lean } \\
\text { Manufacturing }\end{array}$ & 200 & 4.00 & 1.00 & 5.00 & 3.487 & 0.772 & 0.596 \\
\hline $\begin{array}{l}\text { Corrective } \\
\text { Actions }\end{array}$ & 200 & 3.67 & 1.33 & 5.00 & 3.555 & 0.840 & 0.705 \\
\hline $\begin{array}{l}\text { Preventive } \\
\text { Actions }\end{array}$ & 200 & 4.00 & 1.00 & 5.00 & 3.578 & 1.051 & 1.104 \\
\hline Internal Audit & 200 & \begin{tabular}{|l|}
3.33 \\
\end{tabular} & 1.67 & 5.00 & 3.608 & 0.888 & 0.789 \\
\hline Training & 200 & 3.67 & 1.33 & 5.00 & 3.480 & 0.844 & 0.713 \\
\hline \multicolumn{8}{|c|}{ Performance Dimensions } \\
\hline $\begin{array}{l}\text { Market and } \\
\text { Financial } \\
\text { Performance } \\
\end{array}$ & 200 & 3.00 & 1.80 & 4.80 & 3.41 & 0.571 & 0.326 \\
\hline $\begin{array}{l}\text { Operations } \\
\text { Performance }\end{array}$ & 200 & 2.60 & 1.80 & 4.40 & 3.33 & 0.514 & 0.264 \\
\hline $\begin{array}{l}\text { Employees } \\
\text { Performance }\end{array}$ & 200 & 2.80 & 2.00 & 4.80 & 3.42 & 0.563 & 0.316 \\
\hline $\begin{array}{l}\text { Investment and } \\
\text { Development } \\
\text { Performance }\end{array}$ & 200 & 2.60 & 2.00 & 4.60 & 3.26 & 0.498 & 0.248 \\
\hline $\begin{array}{l}\text { Quality } \\
\text { Performance }\end{array}$ & 200 & 3.40 & 1.40 & 4.80 & 3.65 & 0.674 & 0.454 \\
\hline $\begin{array}{l}\text { Customer } \\
\text { Satisfaction }\end{array}$ & 200 & 2.80 & 1.80 & 4.60 & 3.40 & 0.532 & 0.283 \\
\hline
\end{tabular}

\section{COMPARISON OF ORGANIZATIONAL CULTURE AND QUALITY IMPROVEMENT IN COMPANIES THAT BELONG TO A MULTINATIONAL COMPANY SUPPLY CHAIN (GEOGRAPHICALLY DISPERSED COMPANIES)}

In order to compare organizational culture and quality improvement practice in the multinational corporation depending on geographical location of its organizational parts (depending of locations by continents) adequate system of hypothesis is introduced. Geographical location of organizations within multinational supply chain in 32 countries and 6 continents is shown at Figure 1.

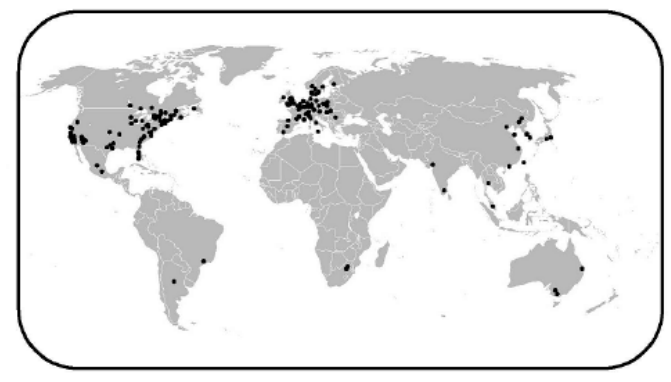

Figure 1. Geographical locations of organizations within the multinational corporation supply chain

The first system of hypothesis considers differences of the mean values of the organizational culture based on the belonging to certain continent.

Null Hypothesis:

$H_{0}: \bar{x}_{1}=\bar{x}_{2}=\bar{x}_{3}=\bar{x}_{4}=\bar{x}_{5}=\bar{x}_{6}$, i.e. there are no significant differences between mean values of organizational culture regarding continent where survey were conducted.

Alternative hypothesis:

$H_{0}: \exists \bar{x}_{i} \neq \bar{x}_{j}, i, j=1, . ., 6$, i.e. there exists at least one significant difference in mean value of the organizational structure regarding the continent where survey was conducted.

Descriptive statistic is shown at Table 3, while adequate ANOVA analysis is presented at Table 4.

Table 3. Descriptive statistics for the first hypothesis system

\begin{tabular}{|l|c|c|c|c|}
\hline Continent & $\begin{array}{c}\text { Number of } \\
\text { companies }\end{array}$ & Sum & Average & Variance \\
\hline $\begin{array}{l}\text { North } \\
\text { America }\end{array}$ & 109 & 385.717 & 3.539 & 0.0156 \\
\hline Europe & 64 & 205.283 & 3.208 & 0.0152 \\
\hline Asia & 16 & 43.467 & 2.717 & 0.0061 \\
\hline $\begin{array}{l}\text { South } \\
\text { America }\end{array}$ & 5 & 14.567 & 2.913 & 0.0005 \\
\hline Australia & 4 & 10 & 2.5 & 0.0042 \\
\hline Africa & 2 & 5.75 & 2.875 & 0.0001 \\
\hline
\end{tabular}

Table 4. ANOVA table for analysis of influence of organizational culture based on Continental disposition

\begin{tabular}{|l|c|c|c|c|c|}
\hline $\begin{array}{l}\text { Source } \\
\text { of } \\
\text { variation }\end{array}$ & $S S$ & $d f$ & $M S$ & $F$ & $p$ \\
\hline $\begin{array}{l}\text { Between } \\
\text { groups }\end{array}$ & 15.756 & 5 & 3.151 & 222.592 & 0 \\
\hline $\begin{array}{l}\text { Within } \\
\text { groups }\end{array}$ & 2.746 & 194 & 0.014 & & \\
\hline Total & 18.502 & 199 & & & \\
\hline
\end{tabular}




\section{$\mathrm{F}_{0}=2.2606$}

Legend: SS - sum of squares, df - degrees of freedom, MS mean square for levels, $\mathrm{F}$ - calculated value of F-test, $F_{0}$ - theoretical value of F-test, $p$-value

Since $p$ value is 0 , null hypothesis cannot be accepted, i.e. there are highly significant differences between average values of organizational culture between contents, for level of significance $\mathrm{p}<0.001$.

The second system of hypothesis tests differences in averages of use of the tools, techniques, methodologies and applications for quality improvement depending on continent which is source of survey.

Null Hypothesis:

$H_{0}: \bar{x}_{1}=\bar{x}_{2}=\bar{x}_{3}=\bar{x}_{4}=\bar{x}_{5}=\bar{x}_{6}$, i.e. there are no significant differences between continents in application of tools, techniques, methodologies and applications for quality improvements.

Alternative hypothesis:

$H_{0}: \exists \bar{x}_{i} \neq \bar{x}_{j}, i, j=1, . ., 6$, i.e. there exist at least one significant difference between continents in application of tools, techniques, methodologies and applications for quality improvements.

Descriptive statistic is shown at Table 5., while adequate ANOVA analysis is presented at Table 6 .

Table 5. Descriptive statistics for second hypothesis system

\begin{tabular}{|l|c|c|c|c|}
\hline Continent & $\begin{array}{c}\text { Number } \\
\text { of comp. }\end{array}$ & Sum & Average & Variance \\
\hline $\begin{array}{l}\text { North } \\
\text { America }\end{array}$ & 109 & 445.918 & 4.091 & 0.0644 \\
\hline Europe & 64 & 215.406 & 3.366 & 0.0840 \\
\hline Asia & 16 & 36.498 & 2.281 & 0.0343 \\
\hline $\begin{array}{l}\text { South } \\
\text { America }\end{array}$ & 5 & 13.135 & 2.267 & 0.0068 \\
\hline Australia & 4 & 11.297 & 2.824 & 0.0002 \\
\hline Africa & 2 & 3.389 & 1.844 & 0.0135 \\
\hline
\end{tabular}

Table 6. ANOVA table for analysis of use of quality improvement depending on continent where company is registered

\begin{tabular}{|l|c|c|c|c|c|}
\hline Source of variation & \multicolumn{1}{c|}{$S S$} & $d f$ & \multicolumn{1}{c|}{$M S$} & $F$ & $p$ \\
\hline Between groups & 70.747 & 5 & 14.149 & 214.329 & 0 \\
\hline Within groups & 12.807 & 194 & 0.066 & & \\
\hline Total & 83.554 & 199 & & & \\
\hline
\end{tabular}

\section{$\mathrm{F}_{0}=2.2606$}

Legend: SS - sum of squares, df - degrees of freedom, MS mean square for levels, $\mathrm{F}$ - calculated value of F-test, $F_{0}$ - theoretical value of F-test, p-value

Since $\mathrm{p}$ value is 0 , null hypothesis cannot be accepted, i.e. there are highly significant differences between quality tools, techniques, methodologies and application in quality improvement that are in use depending of continent of company, for level of significance $p<0.001$.

\section{CONCLUSION}

This paper analyses differences between dimensions of organizational culture and procedures for quality improvement on the sample of 200 companies from 32 countries dispersed worldwide, as a part of multinational corporation supply chain. After detailed review of existing literature, dimensions of organizational culture and quality improvement were analyzed on a large sample of data, to check the differences in organizational culture and quality management practice depending of continent where companies are registered.

Results of conducted empirical research indicate the fact that apart from significant correlation between characteristics of organizational culture and application of procedures for quality improvement, there exist significant differences in both culture and quality management practices depending on the continent where companies are registered. Using analysis of variance and following hypothesis testing there are shown statistically highly significant differences $(p<0.001)$ between average values of organizational culture and quality improvement practices depending on the company location, i.e. continent.

Accordingly, this paper proves that contextual approach promoted in ISO 9001:2015 has to be applied and that organizations which operate in multiple countries must decide how much to localize their organizational culture and related management practices to fit within the host country context.

Future research will be aimed toward examining the existence of significant statistical differences from the observed sample between suppliers and manufacturers in the multinational supply chain, between countries etc. Also, this study is based on a cross-sectional survey conducted on the supply chain level in the aerospace and transportation sector, hence a longitudinal study is a possible future research avenue, too.

\section{REFERENCES}

[1] Boggs B.W.: TQM and Organizational Culture: Case Study, ASQ Quality Management Journal, Vol. 11, No. 2, pp. 42-52, 2004.

[2] Butler, J.M.: Implementation of Quality Management in the Public Sector versus Private Sector: a cultural analysis, Ph.D. thesis, Business School, University of Dublin City, Dublin, 2009.

[3] Cameron, K., Sine W.: A Framework for Organizational Quality Culture, ASQ Quality Management Journal, Vol.6, No.4, pp. 7-25, 1999.

[4] Corbett, L.M., Rastrick, K.N.: Quality performance and organizational culture - A New Zealand study, International Journal of Quality \& Reliability Management", Vol. 17, No.1, pp. 14-26, 2000.

[5] Detert, J.R., Schroeder, R.G., Mauriel, J.J.: A Framework for Linking Culture and Improvement Initiatives in Organizations, The Academy of Management Review, Vol. 25, No.4, pp. 850-863, 2000.

[6] Fonseca, L., Ferro, R.: Influence of firms' environmental management and community involvement programs in their employees and in the community. FME Transactions, Vol. 43, No. 4, pp. 370-376, 2015.

[7] Gambi, L.D.N., Boer, H., Gerolamo, M. C., Jørgensen, F., Carpinetti, L.C.R.: The relationship between organizational culture and quality techniques, and its impact on operational performance. International Journal of Operations \& Production Management, Vol. 35, No. 10, pp. 1460-1484, 2015. 
[8] Ionescu, M.A., Bratosin, S.: Desirable typologies of organizational culture in quality management implementation, communicational findings, Management and Marketing, Vol. 4, No. 3, pp. 77-84, 2009.

[9] Kaluarachchi, K.A.S.P.: Organizational culture and total quality management practices: a Sri Lankan case, The TQM Journal, Vol. 22, No. 1, pp. 41-55, 2010.

[10] Krajcsak, Z.: Successes of quality management systems through self-evaluation and commitment in different organizational cultures: A case study. Management Decision, Vol. 56, No. 7, pp. 14671484, 2018.

[11] Kujala, J., Lillrank, P.: Total quality management as a cultural phenomenon, ASQ Quality Management Journal, Vol. 11, No. 4, pp. 43-55, 2004.

[12] Kull, T.J., Wacker, J.G.: Quality management effectiveness in Asia: The influence of culture, Journal of Operations Management, Vol. 28, pp. 223-239, 2010.

[13] Lagrosen, S.: Exploring the impact of culture on quality management, International Journal of Quality \& Reliability Management, Vol. 20, No. 4, pp. 473-487, 2003.

[14] Luria, G.: Controlling for Quality: Climate, Leadership, and Behavior, ASQ Quality Management Journal, Vol. 15, No. 1, pp. 27-40, 2008.

[15] Man, C.W.: A Study on the Organizational Culture and Total Quality Management Implementation of Construction Companies in Hong Kong, Ph.D. thesis, Faculty of Architecture, University of Hong Kong, Hong Kong, 2005.

[16] Marsden, P.V., Wright, J.D. (Eds.).: Handbook of survey research. Emerald Group Publishing, 2010.

[17] Mathew, J.: The relationship of organizational culture with productivity and quality, Employee Relations, Vol. 29, No. 6, pp. 677-695, 2007.

[18] Naor, M., Goldstein, S.M., Linderman K.W., Schroeder, R.G.: The Role of Culture as Driver of Quality Management and Performance: Infrastructure Versus Core Quality Practices, Decision Sciences, Vol. 39, No. 4, pp. 671-702, 2008.

[19] Pool, S.W.: The learning organization: motivating employees by integrating TQM philosophy in a supportive organizational culture, Leadership and Organization Development Journal, Vol. 21, No. 8, pp. 373-378, 2000.

[20] Prajogo, D.I., McDermott C.M.: The relationship between total quality management practices and organizational culture, International Journal of Operations \& Production Management, Vol. 25, No. 11, pp. 1101-1122, 2005.

[21] Rad, M.A.: The impact of organizational culture on the successful implementation of total quality management, The TQM Magazine, Vol. 18, No. 6, pp. 606-625, 2006.

[22] Spasojevic Brkic, V. and Tomic, B.: Employees factors importance in Lean Six Sigma concept. The TQM Journal, Vol. 28, No. 5, pp. 774-785, 2016.
[23] Spasojević-Brkić, V., Đurđević, T., Omić, S., Klarin, M., Dondur, N.: An empirical examination of quality tools impact on financial performances: Evidence from Serbia. Serbian Journal of Management, Vol. 7, No. 1, pp. 77-87, 2012.

[24] Spasojević-Brkić, V., Klarin, M. and Ivanović, G.: Influence of contingency factors on the application of quality tools. FME Transactions, Vol. 37, No. 3, pp. 143-149, 2009.

[25] Tomic, B., Spasojevic Brkic, V.K.: Customer satisfaction and ISO 9001 improvement requirements in the supply chain. The TQM Journal, Vol. 31, No. 2, pp. 222-238, 2019.

[26] Tomic, B., Spasojević Brkić, V., Karapetrovic, S., Pokrajac, S., Milanović, D.D., Babić, B., Djurdjevic, T.: Organizational culture, quality improvement tools and methodologies, and business performance of a supply chain. Proceedings of the institution of mechanical engineers, Part B: Journal of Engineering Manufacture, Vol. 231, No. 13, pp. 2430-2442, 2017.

[27] Vicente, S., Alves, A.C., Carvalho, S.M. and Costa, N.: Business sustainability through employees involvement: A case study. FME Transactions, Vol. 43, No. 4, pp. 362-369, 2015.

[28]Zu, X., Robbins T., Fredendall L.D.: Mapping the critical links between organizational culture and TQM/Six Sigma practices, International Journal for Production Economics, Vol.86, No.106, pp.86-106, 2010.

\section{NOMENCLATURE}

$\begin{array}{ll}\text { SS } & \text { sum of squares } \\ \text { df } & \text { degrees of freedom } \\ \text { MS } & \text { mean square for levels } \\ F & \text { calculated value of F-test } \\ \mathrm{F}_{0} & \text { theoretical value of F-test } \\ p & \text { value }\end{array}$

\section{ОРГАНИЗАЦИОНА КУЛТУРА И УНАПРЕЪЕЊЕ КВАЛИТЕТА: РАЗЛИКЕ ИЗМЕБУ КОНТИНЕНАТА}

\section{В. Спасојевић-Бркић, Б. Томовић, А. Бркић, 3. Вељковић, М. Мисита}

Претходна истраживанај показују да организациони фактори утичу на програме унапређења квалитета, на начин да су перфомансе предузећа боље када постоји усаглашеност између наведених фактора. Стога је циљ овог рада анализа међузависности организационе културе и програма унапређења квалитета кроз тестирање разлика између димензија организационе културе и техника и процедура унапређења квалитета у компанијама које послују у 32 земље света. Након детаљне анализе претходних истраживања, прикупљени су потребни подаци у 200 предузећа која су део ланца снабдевања мултинационалне компаније. Затим је спроведена статистичка анализа поређења предузећа зависно од 
локације, односно припадности одређеном континенту. Резултати показују да постоје статистички значајне разлике димензија организационе културе и примењених поступака управљања квалитетом зависно од географске локације предузећа. Тако, резултати овог рада потврђују оправданост примене контекстуалног приступа промовисаног у стандарду ИСО 9001:2015 и указују на чињеницу да мултинационалне компаније треба да одреде степен локализације организационе културе и праксе менаџмента квалитетом ради усагалашавања са контекстом земље у којој послују. 